\title{
У царству књига и робота: мејкерспејс у Дечјем одељењу Библиотеке града Београда
}

\author{
Јасна Бркић \\ brkicjasna011@gmail.com \\ Виолета Ђорђевић \\ violeta_djordjevic@yahoo.com \\ Библиотека града Београда
}

\begin{abstract}
Сажетак
У раду се разматрају појам и суштина мејкерспејс (Makerspace) концепта, који се последњих година успешно развија и активно примењује у многим библиотекама, претежно економски развијенијих земаља. Образлаже се потреба деловања у складу са мејкерспејс концептом и трансформације библиотеке у креативни простор у којем се окупљају људи сличних интересовања, усмерених пре свега на рад на рачунарима, бављење техником, електроником, машинама, науком и њеном применом. На примеру Дечјег одељења Библиотеке града Београда описују се почетни кораци у развоју мејкерспејс концепта кроз реализацију пројекта Технотека. Надаље, представљају се радионице реализоване по принципу учења кроз игру, у којима деца и млади стичу нова и проширују постојећа знања и вештине помоћу савремених технологија и анализирају се даље могућности рада на овом пољу у библиотекама.
\end{abstract}

Кључне речи: јавне библиотеке, библиотеке зе децу и младе, мејкерспејс (Makerspace) концепт, едукативне радионице, учење кроз игру, LEGO Education програм, LEGO роботика, 3D технологије, Библиотека града Београда

Дешее се иіра учећи, а учи иірајући.

Е. А. Аркин

\section{Библиотеке у трци с дигиталним временом}

„Уколико јавну библиотеку посматрамо, између осталог, као институцију која помаже решавање одређених проблема у друштву, онда јој треба поставити једно занимљиво питање: ,Са којим друштвеним изазовима би требало да се суоче библиотеке у ери дигиталних технологија?"'11 На ово питање могло би се надовезати и следеће: „У којој мери библиотекари реконцептуализују оквире у којима делају и активности у смеру развоја дигиталних садржаја, доживотног учења и премошћавања дигиталног јаза на путу ка друштву знања? Да ли успевају или не?"2

При покушају да одговоримо на ова комплексна питања, најпре треба констатовати да позајмљивање књига и других врста библиотечке грађе одавно није једини задатак јавних

\footnotetext{
1 Rolf Hapel, „Biblioteke u eri digitalnih tehnologija”, u Planeta Čitalac: priručnik o razvoju publike u bibliotekama, ur. Ivana Jovanović Arsić (Pančevo; Beograd: Gradska biblioteka Pančevo; Udruženje Kulturis, 2014), 29, http://kulturis.org/PlanetaCitalac_Srpski\%20NOVI. pdf (preuzeto 18. 1. 2017).

2 Весна Вуксан и Милица Нинковић, „Међународни информациони односи: дигитални јаз и иницијативе за његово премошћавање”, читалишете број 28 (мај, 2016): 13, http://www.citaliste.rs/casopis/br28/vuksan_vesna_l.html (преузето 23.1.2016)
} 
библиотека. За успешно пословање од приоритетног значаја несумњиво је задовољење све сложенијих потреба корисника. У складу са тим, неке од најважнијих улога које библиотеке преузимају су: омогућавање отвореног приступа знању и онлајн едукацији, пружање подршке преко потребном информационом и информатичком описмењавању, подстицање процеса самообразовања и целоживотног учења. Значајан допринос библиотеке као културно-образовне институције у савременом друштву огледа се, такође, у подржавању стварања идеја, креативности и усвајања нових знања, у новије време, све чешће уз помоћ нових технологија.

Потребама деце и младих већина библиотека прилази с посебном пажњом. У IFLA Cмернииама за библиотеике услуїе за gеиу јасно је наведено да „деци широм света и њиховим породицама библиотечке услуге никад нису биле важније него што су данас. Квалитетна библиотека за децу пружа неопходне вештине за учење током целог живота, оспособљавајући тако децу да учествују и доприносе својој заједници. Она треба непрекидно да реагује на промене у друштву и да задовољава информационе и културне потребе деце, као и њихове потребе за забавом и разонодом". ${ }^{3}$ У складу са наведеним Смернииама, библиотеке широм света испуњавају своје задатке омогућавајући деци да „искусе радост читања и авантуру откривања знања и плодова људског духа". ${ }^{4}$ Библиотекари новог доба, који деле уверења заступника дигиталног оптимизма, ${ }^{5}$ свесни су изузетних могућности информационих технологија у образовном процесу и информатичком описмењавању дигиталних нараштаја. Интересују се и теже проналажењу иновативних начина у примени информационо-комуникационих технологија у раду са децом и младима, са циљем да се подстакне њихов развој, развије медијска култура детета и добије на квалитету образовног процеса. ${ }^{6}$

Ослушкујући потребе деце и младих и у сталној потрази за новим услугама које би задовољиле потребе постојећих и привукле нове кориснике, јавне библиотеке развијених земаља последњих деценија показују иницијативу и покретачки дух перманентно ширећи дијапазон садржаја намењених младој популацији. Тако је, почетком 21. века, у таласу иновација, почело увођење мејкерспејс (енг. Makerspace) концепта у простор јавних библиотека.

\section{Шта је мејкерспејс концепт?}

Термином мејкерспејс означава се креативни простор у ком се окупљају људи сличних интересовања, усмерених пре свега на рад на рачунарима, бављење техником, електроником, машинама, науком и њеном применом. У јавном простору, у неформалној, опуштеној атмосфери, организују се радионице на којима се ради на различитим пројектима, размењују идеје и знања, те усвајају вештине употребе нових дигиталних уређаја и учи путем покушаја и погрешака. Мејкерспејс простор може се сматрати алтернативном образовном институцијом, местом где се кроз практичан рад, мултидисциплинарни приступ и истраживачки процес могу стећи конкретна и корисна знања, која нису предвиђена класичним образовним системом. ${ }^{7}$

\footnotetext{
3 IFLA Секција библиотека за децу и младе, Смернище за библиотечке услуїе за gецу, https://www.nb.rs/view_file.php?file_id=1831, 206. (преузето 16. 1. 2017).

${ }^{4}$ Исто.

${ }^{5}$ Жељко Вучковић, „Кликтање и мишљење: култура књиге и читања у ери интернета", Кулшиура йолиса 9, 18 (2012): 197-211, http:// kpolisa.com/KP18/kp18-IV-2-ZeljkoVuckovic.pdf (преузето 10. 2. 2017).

${ }^{6}$ Violeta Djordjevic and Jasna Brkic, "Playful Learning in Children's Library: New Technologies for Digital Natives", Qualitative and Quantitative Methods in Libraries (QQML) 5 (2016): 301-310, http://www.qqml.net/papers/June_2016_Issue/523QQML_Journal_2016_ DordevicBrkic_301-310.pdf (preuzeto 2. 2. 2017).

7 EDUCASE Learning Initiative, ELI, 7 Things You Should Know About...Makerspace, https://net.educause.edu/ir/library/pdf/eli7095.pdf (preuzeto 22.1. 2017).
} 
Развој мејкерспејс концепта започет је 2005. године у Америци оснивањем америчког часописа Мејк (енг. Make), у чијем су се фокусу нашли „уради сам" (енг. DIY - Do It Yourself) и "уради с другима" (енг. DIWO - Do It With Others) пројекти који подразумевају рад на компјутерима, бављење роботиком, електорником и сродним дисциплинама. ${ }^{8}$ Издавач часописа организовао је потом сајмове, најпре широм Америке, а затим и широм света, промовишући идеју мејкерспејс концепта. У годинама које следе јавне библиотеке су почеле све интензивније да прихватају и уврштавају у своје програмске активности поменути концепт. ${ }^{9}$ Овај пилотпројекат се успешно развио и, последњих година, концепт мејкерспејса је широко примењиван и даље се активно примењује у многим библиотекама углавном економски развијенијих земаља.

Суштину мејкерспејс концепта чини могућност да учесници радионица и пројеката могу да израђују самостално, уз помоћ едукатора или других учесника, дигиталне и физичке предмете у јавном простору делећи понуђену опрему, средства и материјале. Један од кључних момената је тај да се на располагање стављају техничка опрема и помагала велике материјалне вредности које појединци најчешће нису у могућности да сами набаве. Не мање важни су надахњујућа, истраживачка атмосфера, сарадња, открића и знања до којих полазници радионица долазе бавећи се креативним активностима. Мејкерспејс може бити одличан механизам за подстицање ученика да експериментишу и уче ван учионице и устаљених образовних оквира. Практична природа мејкерспејса значајно доприности побољшању вештине учења, које, базирано на решавању проблема, постаје одличан начин да ученици стичу и утврде своје знање. Суочавајући се са проблемима, сами долазе до решења, чинеће знање тако трајнијим и прагматичнијим. ${ }^{10}$

\section{Мејкерспејс у Србији: библиотеке за децу 21. века}

Мејкерспејс концепт је у библиотеке у Србији стигао 2014. године. Међународна невладина организација EIFL-PLIP (Public Library Innovation Programme) ${ }^{11}$ доделила је Народној библиотеци „Душан Матић” из Ћуприје средства за реализацију иновативног пројекта Библиошека++. Покренут је са циљем да децу основношколског узраста, постепено и кроз игру, уводи у свет рачунара и програмирања, а код средњошколаца и студената развија практичне и напредне технике програмирања, стварајући тако нове генерације ИТ стручњака у Србији.

Као основно средство за обуку, Библиотека користи LEGO Mindstorms EV3 комплет за роботику, који омогућава ученицима састављање и програмирање робота који ће се покретати уз помоћ минијатурних електромотора и извршавати разне задатке. Након изградње робота, ученици користе компјутере опремљене софтвером за графичко програмирање како би писали програме који ће им удахнути живот. Након савладаних основа програмирања, деца и млади прелазе на следећи ниво напредних вештина развијајући употребљиве апликације за стварне кориснике, попут оних за решавање математичких проблема, слагалица или видео-игара. Пројекат је добио поршку Локалне самоуправе општине Ћуприја, која је опремила нови Омладински центар и подржала пројекат након периода финансирања кроз EIFL-PLIP програм. ${ }^{12}$

\footnotetext{
${ }^{8}$ Више о часопису Мејк (Make), http://makezine.com/ и https://en.wikipedia.org/wiki/Make_(magazine)

9 John Burke, "Making Sense: Can Makerspace Work in Academic Libraries?", http://www.ala.org/acrl/sites/ala.org.acrl/files/content/ conferences/confsandpreconfs/2015/Burke.pdf, 497, (preuzeto 20. 1. 2017).

${ }^{10}$ Ibid.

${ }^{11}$ EIFL, "Building a new generation of technology experts: Public Library 'Dušan Matic' Cuprija, Serbia", http://www.eifl.net/eifl-in-action/building-new-generation-technology-experts (preuzeto 20. 1. 2017).

${ }^{12}$ Библиотека++, „Циљеви пројекта”, Библиотека++, http://bpp.rs/ciljevi-projekta (преузето 20. 1. 2017).
} 


\section{Мејкерспејс у Дечјем одељењу Библиотеке града Београда: од библиотеке до технотеке}

У октобру месецу 2016. године мејкерспејс концепт почиње да се развија у Библиотеци града Београда. Потреба за овим концептом поникла је из жеље да се, по угледу на савремене светске трендове које постављају неке од највећих библиотека, углавном у Америци и скандинавским земљама, створи hi-tech место за децу и младе, омогући приступ знањима и вештинама изван формалног образовног система и понуди прилика да се у пракси примене информатичка знања која се у школама усвајају махом кроз теорију.

Уз подршку Министарства културе и информисања Републике Србије, у Дечјем одељењу Библиотеке града Београда „Невен” креиран је посебан простор под називом Техношекка. Формиран је мултифункционалан простор у оквиру библиотеке, намењен деци и младима, опремљен различитим дигиталним алатима и училима, који омогућавају корисницима да на бесплатним радионицама, кроз заједнички рад и игру, експериментишу, истражују, продубљују стара и стичу нова знања и вештине из природних наука. Техношеека је опремљена 3D штампачем, 3D скенером, 3D оловком, виртуелним 3D наочарама, LEGO Education роботима WeDo2 и EV3 и неопходном пратећом опремом (паметним телефоном, рачунарима, таблетима, и адекватним софтверима).

Упознајући се са различитим дигиталним технологијама, кроз програмирање, роботику и 3D штампање, млади корисници оснажују своје информатичке и дигиталне компетенције, а библиотека постаје креативна лабораторија која омогућава приступ најновијим технолошким алатима, усмерава и едукује кориснике како да те алате користе на прави начин.

Имајући на уму речи Мајкла Милера (Michael Miller) да је прича о мејкерспејсу „епска прича о путовању библиотекара у информационом добу и да је пут од информационих центара до мејкерспејса брза и паклена вожња", ${ }^{13}$ али са тежњом да библиотека очува своју улогу покретача позитивних промена у друштву, покренут је пројекат Техношеека.

\section{Коцкица по коцкица - LEGO радионица}

Полазећи од чињенице да је концепт мејкерспејса заснован, пре свега, на интерактивности, практичном раду и учењу кроз игру (енг. Edutainment) путем којих се знање усваја на ефикаснији и бржи начин, започето је са реализацијом различитих програмских активности. Појам Edutainment односи се превасходно на софтвере намењене у едукативне сврхе, но може се применити на све врсте дидактичког материјала које деца усвајају кроз забаву и игру уз помоћ нових технологија, ${ }^{14}$ а да притом нису свесна да уче. ${ }^{15}$ Такво „прикривено" 16 учење постаје инспиративно и омогућава деци да уједно усвајају и унапређују и вештине неопходне за 21. век, попут сарадње, комуникације и конструктивног решавање проблема. ${ }^{17}$

Предности LEGO Education програма корисници могу да искусе на бесплатним радионицама које се организују у оквиру Техношееке. Стручњаци чувене данске компаније за производњу играчака LEGO уложили су велики труд да поспеше учење кроз игру, те да усаврше свој

\footnotetext{
${ }^{13}$ Професор Мајкл Милер, аутор бројних публикација, радова и презентација из области библиотекарства, активни је члан ALA (American Library Association) и председавајући Сталног одбора IFLA секције за аудиовизуелну грађу и мултимедију. Предавање о мејкерспејс концепту у библиотекама одржао је марта 2014. године у Америчком кутку у Београду.

${ }^{14}$ Anne Soronen and Sari Walld Walldén, "Edutainment: From Television and Computers to Digital Television", University of Tampere Hypermedia Laboratory, http://www.sis.uta.fi/infim/infim_2011/julkaisut/hyper/b/fitv03b.pdf, 2 (preuzeto 5. 2. 2017).

${ }^{15}$ Zühal Okan, "Edutainment: Is learning at risk?", British Journal of Educational Technology 34 (3) (2003): 255-264, http://web.csulb. edu/ arezaei/ETEC444/discussion/edutainment.pdf (preuzeto 5. 2. 2017).

${ }^{16}$ Andrew Richard Schrock, "'Education in Disguise': Culture of a Hacker and Maker Space", UCLA Journal of Education and Information Studies (2014), http://escholarship.org/uc/item/0js1n1qg (preuzeto 12. 2. 2017).

${ }^{17}$ LEGO Education, https://education.lego.com/en-us/elementary/explore (preuzeto 3. 2. 2017).
} 
производни програм с циљем да деци пруже развојна и образовна искуства. Као резултат тог рада настао је LEGO Education програм, специјално осмишљен да буде подршка професионалцима који раде са децом. ${ }^{18}$ У оквиру њега понуђени су алати за учење путем активног трагања за решењима, који помажу ученицима да постојећа знања продубљују и контекстуализују, односно повезују са свакодневним искуством.

Радионице LEGO програмирања осмишљавају и воде библиотекари Дечјег одељења који су прошли обуку за рад са LEGO роботима, како би, у својству едукатора, помогли деци да начине прве кораке у свет програмирања. Обуку је водио Ален Пиљак, председник удружења ЕдуЛаб, које се бави едукацијом ученика и едукатора у коришћењу LEGO Education дидактичких средстава. У обуци полазника радионица, поред библиотекара, значајну улогу играју и млади волонтери, махом средњошколци, који преносе знања својим вршњацима. Вршњачка едукација испоставила се као изузетно погодан метод за усвајање дигиталних знања и вештина јер одсуство међугенерацијских баријера олакшава комуникацију, а сам процес учења је спонтанији и ефектнији.

Комплет LEGO Education WeDo 2.0, намењен је ученицима млађег основношколског узраста, док је за ученике старијег основношколског узраста и средњошколце посебно атрактиван LEGO Education Mindstorms EV3. Засновани су на једноставној роботској технологији, а заједно са пратећим додацима, дигиталним приручником, софтвером за програмирање и занимљивим, едукативним видео-клиповима, омогућавају да ученици са лакоћом и самопуздањем савладавају основе роботике. Коришћење LEGO Education програма, који укључује основе инжењерства, програмирања и савремену технологију, охрабрује интересовање ученика за науку.

Реализација WeDo 2.0 и Mindstorms EV3 радионица одвија се кроз три етапе: „истражи, направи и подели". У првој етапи водитељ радионице, кроз дискусију и полазећи од дечјих искустава и сазнања, прави увод у одређену тему. Библиотечки материјал и онлајн извори су на располагању како би тему детаљније истражили и надоградили постојећа занања. Тематски оквир који може послужити као увод за игру са роботима је широк, а примера ради, занимљиве теме могу бити: места на нашој планети која су тешко доступна или на којима не постоје услови за живот људи и могући начини њиховог истраживања; сензори и начин њихове употребе; може ли робот поседовати чула која су савршенија од људских; где се користе антене и које машине и уређаји их користе; међупланетарна комуникација - како робот добија инструкције и како шаље информације у базу и др. Библиотекар едукатор мора бити обучен, добро припремљен, али и довољно вешт да препозна интересовања и понуди садржаје који ће бити у зони наредног развоја. „Осетљивост за препознавање дечјих потреба, на чему се данас инсистира у оквиру савремене педагогије, значи управо то: понудити праве садржаје који се налазе у оквиру зоне наредног развоја детета, уместо оних који припадају зони давно пређеног пута (јер дете их је прерасло) и оних који се евентуално налазе у зони будућег развоја (јер дете им није дорасло)". ${ }^{19}$ Прва етапа рада је изузетно захтевна и важна јер се у њој формира мотивишућа, инспиративна и стваралачка радна атмосфера. У другој етапи рада, помоћу препознатљивих LEGO коцкица и других елемената, ученици најпре склапају робота на основу дате шеме, а потом њиме управљају преко апликације за таблет, једноставног интерфејса, чиме програмирање постаје лако и забавно. На располагању су им и приручници за програмирање LEGO робота, попут The LEGO Mindstorms EV3 Discovery Book, The Art of LEGO Mindstorms EV3 Programming итд. Креирајући различите апликације како би манипулисали роботима, учесници кроз игру и практичан рад усвајају и примењују знања предвиђена STEM

\footnotetext{
${ }^{18}$ ИК Креативни центар је једини овлашћени увозник LEGO Education програма за Србију, http://www.kreativnicentar.rs/

${ }^{19}$ Zorica Matejić-Đuričić, "Nove konceptualizacije razvoja i vaspitanja”, Specijalna edukacija i rehabilitacija 11, 2 (2012): 276, http://scindeks-clanci.ceon.rs/data/pdf/1452-7367/2012/1452-73671202267M.pdf\#search="Matejić-Đuričić Zorica (preuzeto 7. 2. 2017).
} 
концептом. Енглески појам STEM је акроним који подразумева неколико научних дисциплина: Science, ${ }^{20}$ Technology, Engineering, Mathematics (природне науке, технологија, инжењерство, математика). ${ }^{21}$ у библиотечкој теорији и пракси све више се наглашава да библиотеке поседују значајне ресурсе и да могу имати водећу улогу у стварању амбијента за спровођење овог концепта. ${ }^{22}$

У последњој етапи радионичарског рада учесници међусобно размењују искуства, презентују продукте свог рада, фотографишу их, праве кратке видео-клипове и по жељи их деле на друштвеним мрежама, чиме се повећава свест шире заједнице о постојању овог пројекта.

\section{Виртуелни свет у три димензије}

Убрзани технолошки развој мења природу креативности и доводи до нових и другачијих кретивних одговора. На темељу схватања да је библиотека место стваралаштва и креативности, настоји се да деци и младима буду доступне модерне технолошке направе и дигитални алати који њихову машту могу претворити у реалност. Под паролом „Измоделујте своју будућност" у Техношещи је омогућено да се заинтересовани корисници баве 3D технологијама и да, поред LEGO програмирања, закораче и у свет 3D моделовања и штампања.

\section{D штампач - идеја на длану}

На бесплатним радионицама, уз помоћ студената са Одсека за индустријски дизајн Факултета примењених уметности и Архитектонског факултета, старији основци и средњошколци имају прилике да се упознају са процесом и могућностима 3D штампања и да на штампачу марке Felix Pro 1 израђују властите тродимензионалне креације, пролазећи кроз процес од цртања жељеног објекта преко 3D моделовања, до штампања 3D модела. Концепт радионице заснива се на интерактивној сарадњи између учесника и предавача и базира се на практичном раду у софтверу.

\section{D скенер - „дигитализовање стварности"}

Корисницима је на располагању и тродимензионални скенер за „дигитализовање стварности". Лагани, практичан, величине таблета, преносиви 3D ручни скенер марке Sense ${ }^{\mathrm{TM}}$ омогућава једноставно и у пуном колору скенирање предмета свих величина, од „игле до локомотиве". Скенер се прикључује на рачунар преко USB конекције, а скенирање комплетног објекта могуће је извести у реалном времену, једним потезом. Квалитетни скенови високе резолуције могу се одмах видети на екрану рачунара и послати директно на 3D штампу. ${ }^{23}$ 3D скенери примењиви су у архитектури, машинству, медицини, дигиталним медијима итд, а корисницима Техношеке, сходно узрасту, на услузи је широк спектар могућности које ова иновативна технологија нуди.

\section{D оловка - идеје у ваздуху}

За оне који се са мрзовољом лате оловке и папира, прави избор, али и изазов у Техношещ,и je 3D оловка (3D Drawing pen RP - 100B), јер уз помоћ ње цртежи добијају трећу димензију.

\footnotetext{
${ }^{20}$ У америчким школама предмет Science подразумева градиво из биологије, хемије, географије и физике.

${ }^{21}$ STEM, http://www.livescience.com/43296-what-is-stem-education.html (preuzeto 10. 2. 2017).

${ }^{22}$ Daniel Gilbert et al., "Leading in and Beyond the Library", Alliance for Excellent Education (2014), http://all4ed.org/wp-content/uploads/2014/01/BeyondTheLibrary.pdf (preuzeto 10. 2. 2017).

${ }^{23}$ Sense ${ }^{\text {TM}} 3 \mathrm{D}$ Scanner, https://www.3dsystems.com/shop/sense (preuzeto 6. 2. 2017).
} 
Једноставна је и лака за употребу, ради на струју, а на компјутер се може прикључити преко USB кабла. Изгледом и обликом подсећа на обичну оловку, а функционише на сличним основама као и 3D принтер. Пошто се укључи у струју и загреје, у оловку се убаци пластична патрона. Притиском на дугме из отвора оловке излази истопљена пластика, која се у додиру са ваздухом хлади и тиме омогућава „писање и цртање” у простору, односно израду 3D структура и облика. Ова технологија отвара широк полигон за играње које, неизоставно, резултира креативним и инвентивним продуктима. Могућност да у тренутку могу да исцртају своју идеју у ваздуху изазов је коме је тешко одолети, а 3D оловка је постала омиљени уређај многим библиотечким корисницима.

\section{D наочаре - поглед у виртуелни свет}

Када се корисницима Техношеке понуди могућност шетње свемиром или подводна морска авантура, реч је, заправо, о виртуелној реалности, која се може искусити, између осталог, виртуелним наочарима. Виртуелна реалност је коришћење рачунарске технологије како би се створила симулирана, тродимензионална средина коју корисник може истраживати или управљати њоме осећајући се као да јој физички припада. ${ }^{24}$ Виртуелне наочаре модела Samsung GEAR VR омогућавају широко видно поље, прецизно праћење кретања главе и брзо урањање у виртуелни свет. Нуде невероватно искуство и „путовања", а авантура неће изостати захваљујући великом избору игара и апликација..$^{25}$ Функционишу уз помоћ паметног телефона омогућавајући гледање 3D филмова и видео клипова, 3D апликација и играње 3D игрица. Али, осим забаве, виртуелна реалност може бити моћан педагошки алат, нпр. за стварање различитих представа о свету који нас окружује и савладавање изазовних појмова у физици. ${ }^{26}$

\section{Закључак}

Развојем мејкерспејс концепта креира се амбијент у коме се чита, испитује, експериментише, размишља, усвајају и повезују знања, а корисницима се уместо тихе библиотеке нуди место активног и гласног трагања за одговорима и закључцима. Овим библиотека успешно обавља своју улогу продужене руке образовног система, активно учествујући у посредовању и реализацији креативних и едукативних активности, испуњавајући тако и важне задатке библиотеке као места целоживотног учења, комуникације и заједничких активности.

Спроводећи основни принцип учења кроз игру у радионичарским активностима, фокус учења са исхода пребацује се на процес, а то је заправо главни зачин који ствара радост при сазнавању и доприноси да деца и млади препознају библиотеку као место целоживотног учења.

Мејкерспејс концепт код корисника који, бавећи се програмирањем и 3D моделовањем, пролазе кроз различите истраживачке процесе, искуствено и креативно учење, ствара потребе за додатном литературом у вези са пољем њихових интересовања, а на тај начин развија се специфична читалачка публика које до сада није било у библиотеци.

Велика заинтересованост деце за радионице организоване у оквиру пројекта Техношекка, као и запажања задовољних и пријатно изненађених родитеља сазнањем да је библиотека место на ком њихово дете може закорачити у област програмирања, LEGO робота и тродимензионалног виртуелног света, потврдили су уверење да мејкерпсејс концепт заслужује своје место међу књигама.

\footnotetext{
24 "Šta je virtuelna realnost i kako VR naočare ustvari funkcionišu", TASTER, https://taster.ba/sta-je-virtuelna-realnost-i-kako-vr-naocare-ustvari-funkcionisu/ (preuzeto 3. 2. 2017).

${ }_{25}^{25}$ SAMSUNG GEAR VR naočare, http://www.samsung.com/global/galaxy/gear-vr/ (preuzeto 6. 2. 2017).

${ }^{26}$ Nada Čitaković, „Primena računara u nastavi fizike”, Vojnotehnički glasnik 56, 2 (2008): 209-216, http://scindeks-clanci.ceon.rs/data/ pdf/0042-8469/2008/0042-84690802209C.pdf (preuzeto 6. 2. 2017).
} 


\section{Литература и извори:}

1. Biblioteka++. "Ciljevi projekta". Biblioteka++. http://bpp.rs/ciljevi-projekta (preuzeto 20. 1. 2017).

2. Burke, John. "Making Sense: Can Makerspace Work in Academic Libraries?". http://www.ala.org/acrl/ sites/ala.org.acrl/files/content/conferences/confsandpreconfs/2015/Burke.pdf, 497 (preuzeto 20. 1. 2017).

3. Čitaković, Nada. „Primena računara u nastavi fizike”. Vojnotehnički glasnik 56, 2 (2008): 209-216. http://scindeks-clanci.ceon.rs/data/pdf/0042-8469/2008/0042-84690802209C.pdf (preuzeto 6. 2. 2017).

4. Djordjevic, Violeta and Jasna Brkic . "Playful Learning in Children's Library: New Technologies for Digital Natives". Qualitative and Quantitative Methods in Libraries (QQML) 5 (2016): 301-310. http:// www.qqml.net/papers/June_2016_Issue/523QQML_Journal_2016_DordevicBrkic_301-310.pdf (preuzeto 2. 2. 2017).

5. EDUCASE Learning Initiative, ELI. 7 Things You Should Know About... Makerspace. https://net.educause. edu/ir/library/pdf/eli7095.pdf (preuzeto 22. 1. 2017).

6. EIFL. "Building a new generation of technology experts: Public Library 'Dušan Matic' Cuprija, Serbia". http://www.eifl.net/eifl-in-action/building-new-generation-technology-experts (preuzeto 20. 1. 2017).

7. Gilbert, Daniel, Rachel Jones and Mary Ann Wolf. "Leading in and Beyond the Library". Alliance for Excellent Education (2014). http://all4ed.org/wp-content/uploads/2014/01/BeyondTheLibrary.pdf (preuzeto 10. 2. 2017).

8. Hapel, Rolf. „Biblioteke u eri digitalnih tehnologija”. U Planeta Čitalac: priručnik o razvoju publike u bibliotekama. Urednik Ivana Jovanović Arsić. Pančevo; Beograd: Gradska biblioteka Pančevo; Udruženje Kulturis, 2014. http://kulturis.org/PlanetaCitalac_Srpski\%20NOVI.pdf (preuzeto 18. 1. 2017).

9. IFLA Sekcija biblioteka za decu i mlade. Smernice za bibliotečke usluge za decu. https://www.nb.rs/view_ file.php?file_id=1831. (preuzeto 16.1.2017).

10. LEGO Education. https://education.lego.com/en-us/elementary/explore (preuzeto 3. 2. 2017).

11. Matejić-Đuričić, Zorica. „Nove konceptualizacije razvoja i vaspitanja”. Specijalna edukacija i rehabilitacija 11, 2 (2012): 267-284. http://scindeks-clanci.ceon.rs/data/pdf/1452-7367/2012/145273671202267M.pdf\#search="Matejić-Đuričić Zorica (preuzeto 7. 2. 2017).

12. Okan, Zühal. "Edutainment: Is learning at risk?". British Journal of Educational Technology 34, 3 (2003): 255-264. http://web.csulb.edu/ arezaei/ETEC444/discussion/edutainment.pdf (preuzeto 5. 2. 2017).

13. SAMSUNG GEAR VR naočare. http://www.samsung.com/global/galaxy/gear-vr/ (preuzeto 6. 2. 2017).

14. Schrock, Andrew Richard. "'Education in Disguise': Culture of a Hacker and Maker Space". UCLA Journal of Education and Information Studies (2014). http://escholarship.org/uc/item/0js1n1qg (preuzeto 12. 2. 2017).

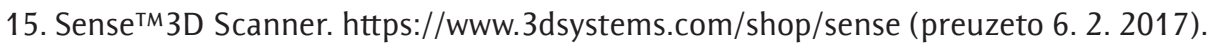

16. Soronen, Anne and Sari Walld Wallden. "Edutainment: From Television and Computers to Digital Television". University of Tampere Hypermedia Laboratory. http://www.sis.uta.fi/infim/infim_2011/ julkaisut/hyper/b/fitv03b.pdf, 2 (preuzeto 5. 2. 2017).

17. STEM. http://www.livescience.com/43296-what-is-stem-education.html (preuzeto 10. 2. 2017).

18. „Šta je virtuelna realnost i kako VR naočare u stvari funkcionišu”. TASTER. https://taster.ba/sta-jevirtuelna-realnost-i-kako-vr-naocare-ustvari-funkcionisu/ (preuzeto 3. 2. 2017).

19. Vučković, Željko. „Kliktanje i mišljenje: kultura knjige i čitanja u eri interneta”. Kultura polisa 9, 18 (2012): 197-211. http://kpolisa.com/KP18/kp18-IV-2-ZeljkoVuckovic.pdf (preuzeto 10. 2. 2017).

20. Vuksan, Vesna i Milica Ninković. „Međunarodni informacioni odnosi: digitalni jaz i inicijative za njegovo premošćavanje". Čitalište broj 28 (2016): 13-24. http://www.citaliste.rs/casopis/br28/vuksan_ vesna_l.html (preuzeto 23. 1. 2017). 


\section{In the Realm of Books and Robots: Makerspace in the Children's Department of the Belgrade City Library}

\section{Summary}

The basic questions raised in this paper are - how well can libraries reconceptualize themselves within the framework of their common initiatives and their activities in the direction of digital development and lifelong learning, and what are the social challenges they face. The makerspace concept is introduced into the libraries as one of the successful solutions for work improvement that is compatible to the needs of the modern age. In the paper, the essence of the concept is being analyzed, with a brief description of its development. The need for the initiative is being discussed. Furthermore, the transformation of the libraries within the makerspace concept is described, through the development of the creative space where people with similar interests can gather in order to deal with computers, technology, electronic devices, machines and applied science. The multiple advantages of acquiring knowledge through the practical work, interdisciplinary approach and the research process in a space that can be considered an alternative educational institution is pointed out. The special attention is drawn to the incredible opportunities this concept offers - e.g., the participants of various workshops and projects can create different digital and physical objects, individually or with the help of educators and other participants, sharing equipment, resources and materials. The initial steps in the development of the makerspace concept are described using the example of the Tehnoteka project realized at the Children's Department of the Belgrade City Library. The workshops in LEGO programming for the students of elementary, middle and high school age, such as workshops in 3D modeling and printing, are explained in great detail. In the implementation of these workshops the principal of learning through play is applied, in which children and young adults acquire new and expand existing knowledge with the help of modern technology, in an informal setting and outside the educational boundaries. At the end, the paper examines the further possibilities for work in this field, and the benefits of introducing the makerspace concept into libraries.

Keywords: public libraries, libraries for children and young adults, makerspace concept, educational workshops, learning through play, LEGO Education, LEGO robotics, 3D technologies, Belgrade City Library 